THE MIDDAY SCHOOL MEAL

A STUDY OF ITS RELATION TO THE TOTAL WEEKLY DIETARY OF A GROUP OF SCHOOLBOYS

BY

\author{
R. P. COOK, M.B., D.Sc. \\ W. A. DAVIDSON, M.D., D.P.H. \\ D. M. KEAY, M.B., D.P.H. \\ AND
}

D. G. McINTOSH, M.B., D.P.H.

(From the Physiology Department, University College, Dundee, and the Public Health Department, Corporation of Dundee)

We are investigating the clinical and nutritional status of a group of boys at a trades school in Dundee. This school undertakes the training of pupils for the six building trades. The boys are drawn substantially from the artisan class, and accordingly represent a uniform cross-section of a portion of the working-class community. The average family income is $£ 4$ 10s. weekly.

This paper, which forms part of a more extended study, is presented to show the contribution of the midday school meal to the total dietary. A short account of some of our findings was given to the Biochemical Society (Cook, Davidson, Keay, and McIntosh, 1944). The relevant data are as follows: (i) Number of subjects, 39 (out of 100 invited to participate); (ii) ages, 14-15 years; (iii) period of study, January to March, 1944. The interest and co-operation of the boys were very striking. The midday meal, which is provided on each of the five school-days (Monday to Friday), is prepared in a central kitchen and distributed to the trades and other corporation schools. A typical meal consists of soup, meat, or fish, with potatoes and greens, and a sweet, usually a milk pudding. Second helpings are allowed. One-third of a pint of milk is given to each boy daily with his midday meal.

\section{Methods of Investigation}

Dietary Intake.-Each boy was provided with a tabular sheet, on which he entered his food intake at each meal for one week. One of us personally instructed each pupil, who at the same time received an explanatory leaflet, to serve as an aid in the method of completing the form. The individual foodstuffs were divided into at least 20 categories, and the values of the constituents in each for one week were obtained by the use of: (a) the food-value calculator of Vitamins Ltd.; (b) food tables given by Davidson and Anderson (1940); $(c)$ bread and potato analyses kindly supplied by the Ministry of Food through the courtesy of Sir Jack Drummond, F.R.S., and Dr. Magnus Pyke. The values obtained are for foodstuffs prepared for consumption. While the methods used are admittedly liable to inaccuracies, it is felt that, taking the results as a whole, reliable data have been obtained. That the dietary results are of the correct order is indicated by the fact that determinations of the total nitrogen in 24-hour samples of urine from the boys gave values of protein equivalent $(\mathrm{N} \times 6.25)$ of 36 to $111 \mathrm{~g}$. per day, mean $68.2 \pm 15.4$ (cf. dietary) protein intake, mean $76.6 \pm 16.4$, in the accompanying Table). The levels of vitamin A and of ascorbic acid in the plasma also bear a general relationship to the dietary intakes.

Presentation of Results.-These are shown in the Table. The range, mean and standard ceviation are given for each set of values. In calculating the standard deviation we have employed the method advocated by Bradford Hill (1942), and for valuable help in this connexion we are greatly indebted to Mr. Ames L. Imrie, C.A., Depute City Chamberlain, Dundee.

\section{Discussion and Summary}

The Table has been made, so far as possible, self-explanatory. The following observations may be of interest:

(i) Considerable individual variations are a striking feature of the total dietary intakes, due probably to the factor of appetite.

(ii) The mean values per day may be compared with the following standards for boys of the same age group, adopted by: (a) the U.S.A. National Research Council (Orr, 1942); $(b)$ the League of Nations Commission (Magee, 1943). Calories (a) 3,200; (b) 2,900; protein (a) 85 g., (b) 95 g.; vitamin A (a) 5,000 i.u., (b) 3,000 i.u.; vitamin $B_{1}$ (a) 533 i.u., (b) 435 i.u.; ascorbic acid (a) $90 \mathrm{mg}$., (b) $30 \mathrm{mg}$.; calcium (a) 1.4 g., (b) $1.5 \mathrm{~g}$.; available iron (a) $15 \mathrm{mg}$., (b) $16 \mathrm{mg}$. The intakes of ascorbic acid and of calcium fall considerably short of both standards, while the intake of vitamin $\mathbf{A}$ is well below the suggested American level.

(iii) The high consumption of national-flour bread is responsible largely for the optimum intake of vitamin $B_{1}$, and to a less extent for the satisfactory level of protein recorded. Although not shown in the table, an interesting feature was that a large proportion of the admittedly low ascorbic acid intake was derived from potatoes, particularly " chips."

(iv) The school meal furnishes a valuable contribution to the total dietary of first-class protein, vitamin $\mathrm{A}$, ascorbic acid, and calcium, the percentages being $44.4+10.3,67.8+12.2,57.8+12.6$, $42.3 \pm 10.9$ respectively. Values for a comparable group of pupils fed exclusively at home are not available, but from our knowledge of local food habits we feel that corresponding figures for a home midday meal would be most unlikely to equal, and would certainly not exceed, the figures given for the school meal.

Table showing Intake of Dietary Constituents for a Group of 39 Boys aged 14-15

\begin{tabular}{|c|c|c|c|c|}
\hline & $\begin{array}{c}\text { Total Amount } \\
\text { Weekly }\end{array}$ & $\begin{array}{c}\text { Total Amount } \\
\text { provided by } \\
\text { School Meals } \\
\text { (i.e., } 5 \text { per week) }\end{array}$ & $\begin{array}{l}\text { Per cent. } \\
\text { from } \\
\text { School } \\
\text { Meals }\end{array}$ & $\begin{array}{l}\text { Amount } \\
\text { per Day }\end{array}$ \\
\hline$\left\{\begin{array}{l}\mathbf{R} \\
\mathbf{M}\end{array}\right.$ & $\begin{array}{l}9,190-28,186 \\
15,341 \pm 3,375\end{array}$ & $\begin{array}{l}3,163-8,575 \\
5,347 \pm 1,017\end{array}$ & $\begin{array}{l}20 \cdot 0-58 \cdot 5 \\
35 \cdot 68 \pm 7 \cdot 0\end{array}$ & $2,191 \cdot 6 \pm 482 \cdot 14$ \\
\hline 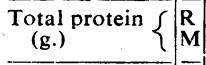 & $\begin{array}{l}375-1,032 \\
536 \pm 114.90 \\
\end{array}$ & $\begin{array}{l}126-301 \\
189 \pm 37 \cdot 24\end{array}$ & $\begin{array}{l}23 \cdot 4-46 \cdot 0 \\
35 \cdot 92 \pm 6 \cdot 1\end{array}$ & $76.57 \pm 16.41$ \\
\hline $\begin{array}{c}\text { First-class } \\
\text { protein (g.) }\end{array}\left\{\begin{array}{l}\mathrm{R} \\
\mathrm{M}\end{array}\right.$ & $\begin{array}{c}151-331 \\
234 \cdot 2 \pm 45 \cdot 37\end{array}$ & $\begin{array}{c}65-145 \\
100 \cdot 8 \pm 17 \cdot 52\end{array}$ & $\begin{array}{l}25 \cdot 7-67 \cdot 3 \\
44 \cdot 4 \pm 10 \cdot 3\end{array}$ & $33 \cdot 46: 6 \cdot 48$ \\
\hline$\underset{\text { (i.u.) }}{\text { Vitamin } A}\left\{\begin{array}{l}\mathbf{R} \\
\mathbf{M}\end{array}\right.$ & $\begin{array}{l}10,300-37,800 \\
20,387 \pm 5,334\end{array}$ & $\begin{array}{c}7,120-20,460 \\
13,430 \pm 2,655\end{array}$ & $\begin{array}{l}38 \cdot 2-84 \cdot 7 \\
67 \cdot 8 \pm 12 \cdot 2\end{array}$ & $2,912 \cdot 4:-762 \cdot 0$ \\
\hline$\underset{\text { (i.u.) }}{\operatorname{Vitamin}_{\mathbf{1}} B_{1}}\left\{\begin{array}{l}\mathbf{R} \\
\mathbf{M}\end{array}\right.$ & $\begin{array}{l}2,946-7,275 \\
4,119 \pm 841\end{array}$ & $\begin{array}{c}865-2,236 \\
1,493 \pm 237\end{array}$ & $\begin{array}{l}19 \cdot 2-52 \cdot 8 \\
37 \cdot 13 \pm 7 \cdot 1\end{array}$ & $588 \cdot 4 \pm 120 \cdot 14$ \\
\hline $\begin{array}{l}\text { *Ascorbic } \\
\text { acid (mg.) }\end{array}\left\{\left\{\begin{array}{l}\mathrm{R} \\
\mathrm{M}\end{array}\right.\right.$ & $\begin{array}{c}98-199 \\
133 \cdot 7 \pm 26.5\end{array}$ & $\begin{array}{c}51-107 \\
75 \cdot 3 \pm 14 \cdot 1\end{array}$ & $\begin{array}{l}32 \cdot 3-81.6 \\
57 \cdot 8 \pm 12 \cdot 6\end{array}$ & $19 \cdot 1 \pm 3 \cdot 79$ \\
\hline $\begin{array}{c}\text { Calsium } \\
\text { (ng.) }\end{array}$ & $\begin{array}{l}3,770-10,050 \\
5,779 \pm 1,348\end{array}$ & $\begin{array}{l}1,340-3,880 \\
2,357 \pm 507\end{array}$ & $\begin{array}{l}25 \cdot 3-61 \cdot 0 \\
42 \cdot 3 \pm 10 \cdot 9\end{array}$ & $825 \cdot 6 \pm 192.57$ \\
\hline $\begin{array}{l}\text { A ailable } \\
\text { iron (mg.) }\end{array}\left\{\begin{array}{l}\mathrm{R} \\
\mathrm{M}\end{array}\right.$ & $\begin{array}{c}47-166 \\
84 \cdot 4 \pm 20 \cdot 3 \\
\end{array}$ & $\begin{array}{c}18-48 \\
30 \cdot 4 \pm 5 \cdot 3\end{array}$ & $\begin{array}{l}19 \cdot 4-53 \cdot 2 \\
37 \cdot 17 \pm 7 \cdot 5\end{array}$ & $12 \cdot 06: 2 \cdot 90$ \\
\hline $\begin{array}{l}\text { Nit. four } \\
\text { bread (oz.) })\end{array}\left\{\begin{array}{l}\mathbf{R} \\
M\end{array}\right.$ & $\begin{array}{l}32-112 \\
74 \cdot 8\end{array}$ & - & $\overline{-}$ & $10 \cdot 7$ \\
\hline
\end{tabular}

$\mathrm{R}=$ Range. $\mathrm{M}=$ Mean. $\pm=$ standard deviation

* The results obtained from three boys during a distribution of oranges, giving values of 69,58 , and $67 \mathrm{mg}$. per day respectively, are omitted.

(v) The general health of the boys was good. The only lesions possibly attributable to dietary deficiencies were gingivitis $(29 \%)$ and folliculosis $(29 \%)$. The relationship of these conditions to the dietary findings is at present the subject of a therapeutic investigation, the results of which we hope to publish later.

Our thanks are due to Dr. W. L. Burgess, C.B.E., and Prof. R. C. Garry for their interest in this work. We are greatly indebted to Mr. Harry Reoch, Headmaster, Trades School, for his keen co-operation.

REFERENCES

C rok, R. P., Davidson, W. A., Keay, D. M., and M=Intosh, D. G. (1944). Biochem J. (In press.)

Davidson, L. S. P., and Anderson, I. A. (194J). A Textbook of Dictetics, Hamish Hamilton, London.

Hill, A. Bradford (1942). Principles of Medical Statistics, Lancet Ltd., London. Magee, H. E. (1943). Publ. Hlth., 5 ô, 125.
Orr, J. B. (1942). Proc. Nutrit. Soc., $1,43$.

\section{THE ORDER OF ST. JOHN}

The report for 1943 of the Chapter-General, the Grand Priory in the British Realm of the Venerable Order of the Hospital of St John of Jerusalem, records its gratitude to members of the medical profession who, despite wartime difficulties, continue to instruct and examine classes in first aid. The strength of the St. John Ambulance Brigade at home increased by 11,098 during the year. More than 24,000 members are serving with H.M. Forces, and more than 60,000 with Civil Defence Services. First aid was given to 489,709 persons during the year; and 285,393 patients, including the victims of 9,254 road accidents, were transported in the Brigade's motor ambulances-more than double the 1942 figure.

The St. John Ambulance Brigade over-seas shows a net increase of 204 new Divisions and of 94 Cadet Divisions. In the South Pacific the Queen of Tonga has become an Associate Dame of the Order in recognition of her great services to humanity. 